\title{
MANAGEMENT MODEL LIMITED CASH TRANSACTIONSFOR THE ERADICATION OF CORRUPTION AND MONEY LAUNDERING IN INDONESIA
}

\author{
Ibrahim Qamarius \\ Malikussaleh Universty \\ iqindo@gmail.com
}

\begin{abstract}
This study aims to: 1) know the management of restrictions on cash transactions; 2) to know the response of the management of related state institutions to the limitation of cash transactions; 3) to know the involvement of human resources in the management of restrictions on cash transactions; 4) find out the amount of restrictions on cash transactions expected by the management of relevant state institutions; 5) to know the coordination and supervision among related state institutions in realizing the Law on Limitation of Cash Transaction in Indonesia. This study uses case study method in several state institutions, namely 1) Financial Transaction Reporting and Analysis Center: 2) Bank Indonesia; 3) National Legal Development Board, Ministry of Justice and Human Rights; And 4) of the People's Legislative Assembly of the Republic of Indonesia. Data collection is done through observation, interview, documentation and focus group discussioin. Data analysis is done descriptively and qualitatively. The research resulted in: 1) the management of restrictions on cash transactions made with relevant state institutions already exist; 2) the responses of state institutions' management to the very positive cash transaction restriction, in their view and their response that the restrictions on cash transactions will prevent corruption and various forms of money laundering in Indonesia; 3) all relevant state institutions have involved human resources in conducting studies and even been directly involved in meetings on restrictions on cash transactions; 4) for the initial phase all the relevant state institutions agree the amount of cash transaction restrictions Rp. 100,000,000, (one hundred million rupiah); 5) coordination among related state institutions in realizing the Law on Restrictions on Cash Transactions in Indonesia has been well coordinated.
\end{abstract}

Keywords: Management, Restrictions on Cash Transaction, CorruptionEradication, Money Laundering

Indonesia is one of the most corrupt countries in the world, one of the targets of narcotics and other illicit drugs, the target of international terrorism and money laundering. Where in fighting it more oriented to the action of action rather than prevention, which should be done proportionally (comparable).

In the case of the eradication of corruption, in which the captured corruptors are confiscated or fined, all the property of foreclosures and penalties are reinserted into the state treasury, then into the State Budget (APBN), then corruption again and so on. So that corruption in Indonesia continues to happen and repeatedly like no end. So also in the fight against money laundering (money laundering) in Indonesia is more likely to action than prevention.

In the fight against corruption and other money laundering in Indonesia, various laws and regulations have been developed and implemented, such as Bank Indonesia Regulation Number 3/10 / PBI / 2001 jo Bank Indonesia Regulation Number 3/23 / PBI / 2001 Concerning Principles Know Your Customer or Know Your Customer (Bank Indonesia, 2001). In addition, Law Number 15 Year 2002 on the Crime of Money Laundering, dated April 17, 2002, Law Number 25 Year 2003 on Money Laundering Crime Act No. 8 of 2010 on Prevention and Eradication of Criminal Acts of Purgatory Money and other legislation (PPATK, 2010). Where all these regulations / legislation has not been effective in combating corruption and other money laundering in Indonesia.

For that, prevention efforts are needed so that money does not fall into the hands of criminals. Prevention is far more important than prosecution or prosecution. Nevertheless, 
prosecution or prosecution is necessary to uphold the rule of law in Indonesia. But there must be a balance with prevention efforts (preventive) in the future. In terms of cost, prevention is obviously cheaper than any other remedies. Because, if the money has been corrupted, it will cost a lot to return the money to the state. In addition, additional costs are required, such as the cost of pursuit, pick-up, detention and more. One of the prevention efforts can be done through restrictions on cash transactions.

Based on the description on the background of the problem, the researcher focuses this research on the Management of Cash Transaction Restrictions for the Eradication of Corruption and Money Laundering in Indonesia. Where in general this study aims to analyze and describe the Management of Restrictions on Cash Transactions for the Eradication of Corruption and Money Laundering in Indonesia.

\section{Management}

Mary Parker Follet states that management is the art getting thingsdone thought people, that is as an art to get everything done through others (Wibowo, 2012). While Dubrin (1990: 5) defines management as a process using organizational resources to achieve organizational goals through the functions of planning and decision making, organization, leading, and controlling.

Management is a process of planning, organizing, leading, and overseeing the work of available organizational members to achieve clearly stated organizational goals (Stoner and Freeman, 1992: 4). While Robbins and Coutlar (1996: 6) provide a partial management definition of a process to make activities resolved efficiently and effectively with and through others.

Thus, it can be concluded that management is the process of using organization resources by using others to achieve organizational goals efficiently and effectively.

\section{Human Resource Management}

Human resource management is the policy and practice in mobilizing human resources or aspects related to management positions in human resources that include the activities of recruitment, screening, training, awards and assessment (Dessler, 2011: 4). According to Noe, Hollenbeck, Gerhart and Wright (2008: 4) human resource management are policies, practices, and systems that affect the habits, attitudes, and performance of an employee. Meanwhile, according to Snell and Bohlander (2010: 4) human resource management is the process of organizing human skills to achieve organizational goals.

According to Byars and Rue (2005: 4) human resources management is an activity that is designed to provide and coordinate human resources in an organization. Meanwhile, according to Mathis and Jackson (2006: 3) human resource management is the design of formal systems within an organization to ensure the effective and efficient use of human talent to achieve organizational goals.

\section{Cash Transaction Limitations}

Limitation of cash transactions is a mechanism or system to limit transactions with cash, where transactions above the specified limits must be made through the banking system. For example, cash transactions are limited to Rp. 100.000.000, - (one hundred million rupiah) or Rp. 50.000 .000 , - (fifty million rupiah) in 1 (one) day, where transactions above the limit must be made through the banking system (Qamarius, 2010).

According to the Draft Law of the Republic of Indonesia on Restrictions on Cash Transactions of 2016, the Kartal Money Transaction is a withdrawal, disbursement, purchase, payment, grant, sale and other activities using currency. According to the Head of Financial Transaction Analysis and Analysis Center (PPATK) Muhammad Yusuf, the PPATK targets the Bill to restrict cash transactions to be completed by 2016. PPATK has met with Bank Indonesia, the Minister of Finance and other related parties and has drafted -The Limitations on the Cash Transaction (Yusuf, 2016).

\section{Corruption}

In Indonesian General Dictionary, corruption is as cheating, bribery, and immoral 
(Poerwadarminta, 1976: 12). Meanwhile, according to Big Indonesian Dictionary, corruption is a misappropriation or embezzlement of state money or company and so on for personal interest and others (Ali, 1999: 15).

According to the Law of the Republic of Indonesia Number 30 Year 2002, Corruption is a criminal act as referred to in Law Number 31 Year 1999 concerning the Eradication of Corruption as amended by Act Number 20 of 2001 concerning the Amendment Of Law Number 31 Year 1999 concerning the Criminal Act of Corruption. In Law Number 31 Year 1999 concerning the Eradication of Corruption which was then amended through Law Number 20 of 2001, then in Article 2 paragraph (1) to formulate the criminal act of corruption is: "Any person who unlawfully commits the act Enrich themselves or others or a corporation that may harm the state finance or the economy of the country, shall be liable to a life imprisonment or imprisonment of a maximum of 4 (four) years and a maximum of 20 (twenty) years and a minimum fine of Rp. 200.000.000, - (two hundred million rupiah) and at most Rp. 1.000.000.000, - (one billion rupiah) ".

According to Transparency Intertasional, corruption is the behavior of public officials, both politicians / politicians and civil servants, who unreasonably and illegally enrich themselves or enrich those close to him by abusing the public power entrusted to them. The act of corruption includes the elements: violates applicable law, abuse of authority, harms the state, enriches the person / self (Rudito \& Famiola, 2007: 78).

\section{Money laundering}

What is meant by money laundering or money laundering in Indonesia, according to Law Number 25 Year 2003 concerning Money Laundering Crime provides the definition of money laundering in Article 1 number 1 which reads as follows:

"Money laundering is the act of placing, transferring, paying, spending, donating, donating, entrusting, bringing out the country, exchanging, or other acts of property knowingly or suspected to be the proceeds of a crime for the purpose of concealing or disguising the origin of property The wealth of sehinnga seems to be a legitimate property".

Whereas pursuant to Law Number 8 Year 2010 on Prevention and Eradication of Money Laundering Crime, money laundering is any act which fulfills the elements of crime in accordance with the provisions of this Law.

In this sense, the elements in question are the element of the perpetrator, the element of the act against the law and the element is the result of a crime. While the definition of money laundering crime can be seen in Article (3), (4), and (5) of Law Number 8 Year 2010. The point is that money laundering is a form of crime committed by either person and / or The corporation intentionally locates, transfers, transfers, spends, pays, grants, entrusts, takes abroad, changes the form, exchanges with currency or securities or other acts of property which it knows or reasonably suspects is the proceeds of a crime in order to hide Or disguise the origin of the property, including those who accept and carry it.

The United Nations Convention (UN) on the Prevention and Eradication of Illegal Illicit Trafficking in Narcotics, Hazardous Drugs and Psychotropics 1988 (The United Nations Convention Against Illicit Traffic in Narcotics, Drugs and Psychotropic Substances of 1988) defines money laundering as:

"The convertion or transfer of property, knowing that such property is derived from any serious (indictable) offence or offences, or from act of participation in such offence or offences, for the purpose of concealing or disguising the illicit of the property or of assisting any person who is involved in the commission of such an offence or offences to evade the legal consequences of his action; or The concealment or disguise of the true nature, source, location, disposition, movement, rights with respect to, or ownership of property, knowing that such property is 
derived from a serious (indictable) offence or offences or from an act of participation in such an offence or offences".

(Conversion or transfer of property, acknowledging that the property comes from a serious (accused) offense or offense, or from an act of participation in a crime or offense, for the purpose of concealing or disguising illegitimate property or assisting any person engaged in a commission such as a Violation or infringement to circumvent the legal consequences of his actions, or concealment or improper possession of the true nature, source, location, nature, movement, property or property rights, knowing that the property is from a serious person (can be accused) Violation or offense or from an act such as participation in a crime or offense).

\section{METHOD}

Qualitative research approach, with case study research method is expected for the results of research can be clear and deep. The data collection techniques and procedures are preceded by observation, as a preliminary before the observation has been notified through the letter of the visit plan and the design of data that will be requested for timely interviewing and estimation of the required data can be prepared. Data to be collected are data related to the management of cash transaction restrictions for corruption eradication and money laundering in Indonesia, which will be collected through questionnaires to leaders or officials at relevant state institutions.

Data were collected through observation, interview, data collection through documentation and focus group discussion. Data collection through observation by observing, observing and scrutinizing and recording behavior systematically for a particular purpose so that it can be used to provide a conclusion or diagnosis. Data collection through interviews by way of conversation is done by two parties, with interviewers who ask questions and interviewers who provide answers to these questions. Thus the researcher prepares some questions and asks the willingness of time to the sample that has been determined to do the interview in order to get the planned data. Data collection through document studies in which the researcher performs by viewing or analyzing the documents made by the apparatus / employee to get a picture from the subject's point of view through a written medium and other documents. Data collection through focus group discussion or other terminology is focus group discussions are interviews conducted in groups to collect information from different angles of view required a form of interview conducted jointly in one time and one place.

Data collection of data verification through experts also done data reduction and coding as mentioned above. Further data collected through the document is done script or recapitulation data. Through the recapitulation of interview data and verification data and document data so that it can easily find the final conclusion related to the management of cash transaction restrictions to eradicate corruption and money laundering in Indonesia. The implementation of the research has prepared adequate time research, selecting informants or people who will be the informant or data source selected by leaders / officials who master and really understand the data collected. Furthermore, after data collected through interviews collected data through documentation and verification of data to experts or officials who have authority for the management of restrictions on cash transactions. Each time the interview conducted data reduction so it is easier to know that each theme is known through interviews with whom and there are on line to how. After doing data reduction followed by coding or coding so that each subject has been done code of who the informant, interview code how, the date of how to do interview and there are on line how. With the implementation of the coding will easily megetahui conclusion of each theme and subtema, so that the data obtained is really credible and or trustworthy. 


\section{Research result}

\section{RESULTS AND DISCUSSION}

The research findings on the management of cash transaction restrictions collected through observation, documentation, interview and focus group discussion are as follows:

a. Management of Cash Transaction Restriction

The management of the cash transaction restrictions made with the relevant state institutions already exists. While management of cash transaction restrictions in Indonesia consists of PPATK as coordinator, in coordination with $\mathrm{OJK}$ and $\mathrm{BI}$ and other related state institutions to oversee Financial Service Providers (FSA) including: a) banks; B) the organizer of the post; C) the organizer of emoney and / or e-wallet; D) the organizer of money remittance activities; And e) Other PJKs that provide payment services.

b. Response of the Head of the State Institution Related

The response of the management of related state institutions to the limitation of cash transactions is very positive, in their view and their response that the restrictions on cash transactions will prevent corruption and various forms of money laundering in Indonesia. However, because the application of cash transaction restrictions is expected to affect the funding of political parties, the possibility of the Cash Transaction Restriction Act is not supported by Members of the House of Representatives.

c. Involvement of Human Resources

For the involvement of human resources in the limitation of cash transactions, all relevant state institutions have involved human resources in conducting studies and even been directly involved in various meetings on restrictions on cash transactions, such as in the preparation of Academic Draft, Drafting of Cash Transaction Limitation Draft and Coordination meeting among other institutions. However, all relevant state institutions have not yet established a special department / section which is authorized / responsible to handle the restrictions on cash transactions.

d. Amount of Restrictions on Cash Transactions

For the amount of restrictions on cash transactions in Indonesia, all relevant state institutions agree that for the initial phase of the cash transaction restriction is Rp. 100.000.000, - (one hundred million rupiah). Where the amount of cash transaction restrictions in Indonesia is due to consider the readiness of banks and the public. In addition, the number of such restrictions is in accordance with the Academic Paper and the Draft Law on Cash Transaction Limitations involving various relevant state institutions.

e. Coordination and Supervision among the Related State Institutions

Coordination among related state institutions in the realization of the Cash Transaction Restriction Act in Indonesia has been well coordinated, as can be seen from the participation of relevant state institutions in completing the preparation of Academic Draft, Drafting of the Cash Transaction Limitation Act and participation in inter-agency meetings. All relevant state bodies agreed not to be required to establish a special agency / agency for the management of cash transaction restrictions, as agreed upon in the inter-agency meeting have been agreed to give PPATK wider authority.

Management of cash transaction restrictions is led by the Financial Transaction Reporting and Analysis Center (PPATK), coordinating with Bank Indonesia, the Financial Services Authority, the Ministry of Finance and other relevant state institutions. The management of cash transaction restrictions is as in Figure 4.1 below: 


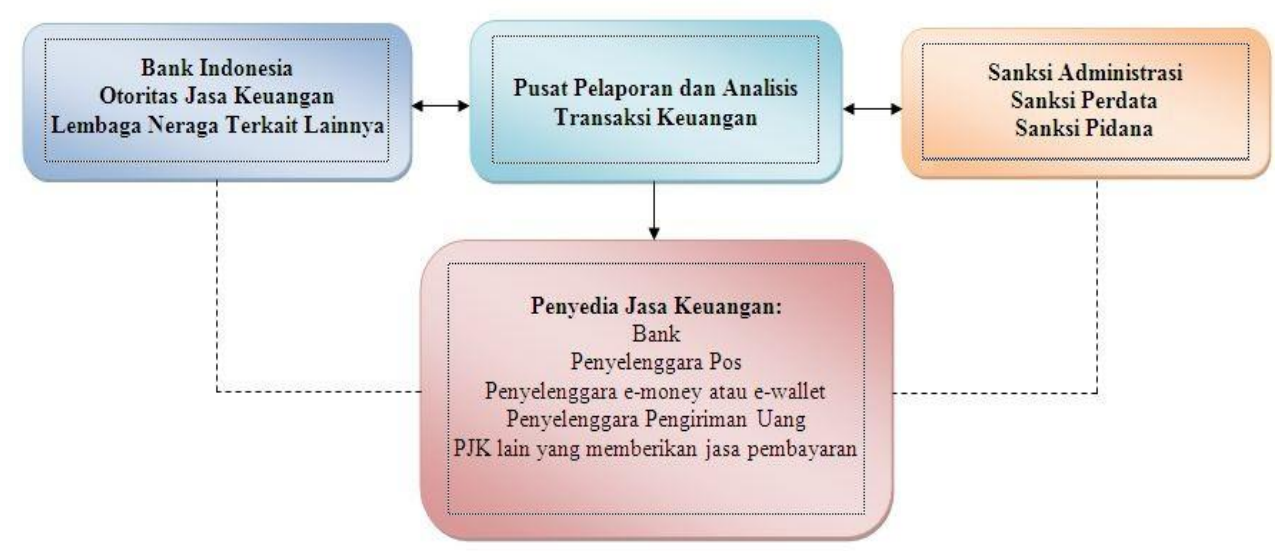

Figure 4.1 Management of Cash Transaction Restrictions

\section{Discussion of Research Findings}

Based on the research findings as described in the research results, the discussion of research findings are as follows:

a. Management of Cash Transaction Restriction

The findings of research conducted by researchers through observation and interviews with PPATK Legal Director, Director of Internal Management Legal Affairs of Bank Indonesia, Head of National Legal Development Board (BPHN) of the Ministry of Law and Human Rights and Chairman of the National Legislation Board on the management of cash transaction restrictions, obtained data That the management of restrictions on cash transactions made in conjunction with other relevant state institutions already exists.

While management of cash transaction restrictions in Indonesia consists of PPATK as coordinator, in coordination with $\mathrm{OJK}$ and $\mathrm{BI}$ and other related state institutions to oversee Financial Service Providers (FSA) including: a) banks; B) the organizer of the post; C) the organizer of emoney and / or e-wallet; D) the organizer of money remittance activities; And e) Other PJKs that provide payment services.

b. Response of the Head of the State Institution Related

From the data collected by the researchers through interviews to obtain data on the management of cash transaction restrictions, obtained data that the response or views of PPATK Legal Director on the limitation of cash transactions is very positive, because the restrictions on cash transactions will be able to prevent corruption and various forms of money laundering in Indonesia.

Similarly, the response or views of Director of Internal Management Legal Affairs of Bank Indonesia on the limitation of cash transactions is very good, given the limitation of cash transactions one solution to prevent corruption and various forms of money laundering that are rooted in various aspects of life in Indonesia.

While the response or the views of the Head of the National Legal Development Agency (BPHN) of the Ministry of Law and Human Rights on the restrictions on cash transactions is also very good, because the limitation of cash transactions will be able to prevent corruption and various forms of money laundering in Indonesia.

Similar responses and views were also conveyed by the Chairman of the National Legislation Body of the House of Representatives (DPR) which strongly supported the implementation of the limitation of cash transactions in Indonesia, as it is believed that the limitation of cash transactions will reduce corruption and other money laundering in Indonesia. Because although it can not remove it entirely, with a cash transaction restriction of at least $90 \%$ of corruption and other money laundering issues will be resolved. 
It is thus apparent that all officials of the relevant state institutions interviewed provided support and responded very positively, as the limitation of cash transactions was considered to be a prevention solution in the eradication and other money laundering in Indonesia.

Institutionally, the PPATK leadership's response to the cash transaction restriction is also very positive, even PPATK has become an institution that is at the forefront to realize the application of cash transaction restrictions in Indonesia.

The management response of Bank Indonesia to the limitation of cash transactions is very good as well, where Bank Indonesia is always present in meetings or meetings held by PPATK and will actively participate in the implementation of cash transaction restrictions.

Similarly, BPHN's management response to the limitation of cash transactions is very good, in which BPHN in cooperation with related parties has conducted the study of Academic Paper to prepare the Draft Law on Cash Transaction Restrictions, and other matters related to the restrictions on cash transactions.

Meanwhile, Chairman of the National Legislation Board estimates that the Leadership and Members of the House of Representatives in principle support the limitation of cash transactions, because the limitation of cash transactions is an ideal for prevention in combating corruption and other money laundering in Indonesia. However, according to him, because the application of cash transaction restrictions is expected to affect the funding of political parties, the possibility of the Cash Transaction Restriction Act is not supported by some members of DPR-RI. So that the need for a solution, such as the ratification of the Cash Transaction Restriction Act in conjunction with the Law on Financing of Political Parties.

It is thus apparent that the management of the relevant state institutions also provided support and responded very positively, as the limitation of cash transactions was considered to be a prevention solution in the eradication and other money laundering in Indonesia. However, there is a possibility that the Leaders and Members of the DPR-RI are not expected to support the limitation of cash transactions because it will affect the funding of political parties.

c. Involvement of Human Resources

For the involvement of human resources in the limitation of cash transactions, all human resources in PPATK are directed to engage in restrictions on cash transactions. While human resource involvement in the restriction of cash transactions, some Bank Indonesia employees have been directed to review and be directly involved in any meeting on the restrictions on cash transactions.

While the involvement of human resources in the limitation of cash transactions, BPHN is involved in order to prepare the Cash Transaction Limitation Bill. While other fields are generally the policy of the Ministry of Justice and Human Rights. While the involvement of human resources in the limitation of cash transactions, members of the House of Representatives especially from Commission III have reviewed, held meetings with related parties related to the restrictions on cash transactions.

In connection with the department / special section given the authority / responsibility to handle the restrictions on cash transactions, all relevant state institutions have not formed them.

Thus, all relevant state institutions have already engaged in human resource involvement in the limitation of cash transactions. But no one has formed a department / special section.

d. Amount of Restrictions on Cash Transactions

As for the amount of restrictions on cash transactions in Indonesia, all relevant state institutions agree that for the initial phase of the ideal cash transaction limitation of Rp. 100.000.000, - (one hundred million rupiah).

While the reason for the amount of cash transaction restriction in Indonesia is because in addition to the consideration of the readiness of banks and the public, the amount of such restrictions 
is in accordance with Academic Paper and the Criminal Law of Cash Transaction Restrictions involving various related state institutions.

e. Coordination and Supervision among the Related State Institutions

With regard to coordination among related state institutions in realizing the Cash Transaction Restriction Act in Indonesia, according to the PPATK has been well coordinated, it is seen from the participation of relevant state institutions in various respects. Likewise, according to Bank Indonesia, the coordination among related state institutions in realizing the Cash Transaction Restriction Act in Indonesia has started well coordinated, with the hope that the Government and the People's Legislative Assembly of the Republic of Indonesia may approve the implementation of cash transaction restrictions.

Meanwhile, according to the BPHN, the coordination between the relevant state institutions in realizing the Law on the Cash Transaction Restriction in Indonesia has been well coordinated, it is seen that all related parties have jointly compiled Academic Paper and Draft Law on Cash Transaction Restriction.

Meanwhile, according to the DPR-RI coordination between the relevant state institutions in realizing the Law of Cash Transaction Restrictions in Indonesia is good, because the Law on Cash Transaction Restrictions will be realized if there is coordination between the Government and the House of Representatives.

Thus it is seen that all related parties consider the coordination between the relevant state institutions in realizing the Law on Restrictions on Cash Transactions in Indonesia is good, this condition needs to be maintained and improved in the future.

Related to the obstacles in realizing the Law of Cash Transaction Restriction in Indonesia, according to the PPATK because the personnel sent by related institutions often change or change. Meanwhile, according to the Bank Indonesia, the obstacle in realizing the Law of Cash Transaction Restrictions in Indonesia, because many parties have not agreed with the restrictions on cash transactions.

Meanwhile, according to the BPHN, the obstacle in realizing the Cash Transaction Restriction Act in Indonesia is the absence of a special unit / unit in charge of the restriction of cash transactions, so that representing the state institutions in the preparation of the Cash Transaction Limitation Bill often change frequently.

Meanwhile, according to the House of Representatives, the obstacle in realizing the Law of Cash Transaction Restrictions in Indonesia, will likely be rejected by the Parliament if there is no solution about the financing of political parties.

In the case of establishing a special agency / agency for the management of cash transaction restrictions, all relevant state institutions consider unnecessary as based on agreement of inter-agency meetings have been agreed to give wider authority to PPATK.

\section{CONCLUSION}

The management of the cash transaction restrictions made with the relevant state institutions already exists. Similarly, the responses of state institutions' management to the limitation of cash transactions are very positive, in their view and their response that the restrictions on cash transactions will prevent corruption and various forms of money laundering in Indonesia. In addition, all relevant state institutions have involved human resources in conducting studies and even been directly involved in various meetings on restrictions on cash transactions. As for the initial stage all the relevant state institutions agreed the amount of cash transaction restrictions Rp. 100.000.000, (one hundred million rupiah). While coordination among related state institutions in realizing the Law of Cash Transaction Restrictions in Indonesia has been well coordinated. 


\section{REFERENCES}

Amstrong, Michael. (2004). Performance Management. Yogyakarta: Tugu Publish.

Amstrong, Michael, and Angela Baron. (1998). Performance Management. London: Institute of Personnel and Development.

Asian Development Bank. (2003). "Manual on Countering Money Laundering and The Financing of Terrorism".

Bacal, Robert. (1999). Perpormance Managemant. New York: The McGraw-Hill.

Bank Indonesia. (2001). "Prinsip Mengenal Nasabah dan Anti Pencucian Uang".

Bank for International Settlements. (1998). "Prevention of Criminal Use of the Banking System for the Purpose of Money-Laundering”.

Badan Pembinaan Hukum Nasional Kementerian Hukum dan Hak Asasi Manusia, Naskah Akademik Rancangan Undang-Undang Pembatasan Transaksi Tunai, 2013.

Bucy, Pamela, H. (1992). White Collar Crime: Cases and Materials. St. Paul, Minn: West Publishing Co.

Buku Saku Korupsi. (2003). Memahami Untuk Membasmi, Jakarta: Komisi Pemberantasan Korupsi Republik Indonesia.

Byars, Lloyd L., \& Leslie W. Rue. (2005). Human Resource Management. Ninth Edition, New York: McGraw Hill.

Cooper Donald R, Schindler Pamela S. (2006). Metode Riset Bisnis, Volume 1, Edisi 9, dan Volume 2, Edisi 9, Jakarta: PT Media Global Edukasi.

Dessler, Gary. (2011). Human Resource Management, Global Edition, New Jersey: Pearson Higher Education. . (2010). Manajemen Sumber Daya Manusia, Edisi Kesepuluh Jilid 1. Jakarta : Indeks. . (2010). Manajemen Sumber Daya Manusia, Edisi Kesepuluh Jilid 2. Jakarta : Indeks

Dyck, Bruno \& Neubert, Mitchell. (2009). Management: Current Practices and New Directions, 1st Edition, South-Western: Cengage Learning.

European Union. (2012). "Commissioner Michel Barnier welcomes the adoption of revised international standards in support of the fight against Money Laundering and Terrorist Financing”, 16 Februari.

Financial Action Task Force. (2003). "40 Recommendations and Basel Committee on Banking Supervision", Oktober. . (2004). "The 40 Recommendations", Fatf Gafi, Oktober. . (2012). FATF Members and Observers, Fatf Gafi.

Financial Crime Prevention Project. (2006). Manual Pelatihan dan Persiapan Ujian CFE (Certified Fraud Examiner) untuk KPK, BPK, PPATK, Inspektorat Jenderal dan Kejaksaan Agung.

Ganarsih, Yenti. (2009). Kriminalisasi Pencucian Uang (Money Laundering), Jakarta: FHUI.

Ghozali, Imam. (2005). Aplikasi Analisis Multivariate dengan Program SPSS, Semarang: Badan Penerbit Universitas Diponegoro.

Hornby, A.S. (2005). Oxford Advanced Learner's Dictionary, Oxford: Oxford University Press.

Husein, Yunus. (2003). Rahasia Bank: Privasi Versus Kepentingan Umum, Jakarta: Pascasarjana FH UI.

Ivancevich, John M, at. al. (2007). Perilaku dan Manajemen Organisasi. Jakarta: Erlangga.

Kerzner, Harold. (2001). Project Management, Seventh Edition. New York: John Wiley \& Sons, Inc.

Komisi Pemberantasan Korupsi. (2002). Undang-Undang No. 20 Tahun 2001 Tentang Pemberantasan Tindak Pidana Korupsi.

Lilley, Peter. (2003). Dirty Dealing: The Untold Truth About Global Money Laundering, International Crime and Terrorism, London and Sterling, VA: Kogan Page Limited.

Moleong, Lexy J. (2011). Metode Penelitian Kualitatif, Bandung: Remaja Rosdakarya.

Noe, Raymond A., John R., Hollenbeck, Barry, Gerhart dan Patrick M., Wright. (2010). Manajemen Sumber Daya Manusia, Edisi Kesepuluh, Jakarta: Indeks.

Peraturan Bank Indonesia. (2010). Nomor: 12/20/PBI/2010, Penerapan Program Anti Pencucian Uang (APU) dan Pencegahan Pendanaan Terorisme (PPT) bagi Bank Perkreditan Rakyat dan Bank Pembiayaan Rakyat Syariah.

Pusat Pelaporan dan Analisis Transaksi Keuangan, Undang-Undang tentang Pencucian Uang, 2011.

Peraturan Bank Indonesia. (2009). Nomor: 12/20/PBI/2010, Penerapan Program Anti Pencucian Uang dan Pencegahan Pendanaan Terorisme Bagi Bank Umum, 
Rancangan Undang-Undang Republik Indonesis tentang Pembatasan Transaksi Uang Kartal, 2013. Rancangan Undang-Undang Republik Indonesis tentang Pembatasan Transaksi Uang Kartal, 2016.

Robbins, Stephen P. \& Mary K, Coulter. (2007). Management, Ninth Edition, New Jersey, Pearson Prentice Hall.

Rudito, Bambang dan Famiola, Melia. (2007). Etika Bisnis Dan Tanggung Jawab Sosial Perusahaan, Bandung: Rekayasa Sains.

Schermerhorn. (2005). Management, 8th Edition, USA: John Wiley \& Sons Inc.

Sugiyono. (2009). Metode Penelitian Pendidikan Pendekatan Kuantitatif, Kualitatif, dan $R \& D$. Bandung: Alfabeta.

Terry, George R. dan Rue, Leslie W. (2005). Dasar -Dasar Manajemen, Jakarta: Bumi Aksara.

Wagner, John A dan John R, Hollenbeck. (2010). Management of Organizational Behavior, Securing Competitive Adventage, New York: Routledge.

Wibowo. (2014). Manajemen Kinerja, Edisi Keempat, Jakarta: PT. Raja Grafindo Persada.

Qamarius, Ibrahim. (2014). Analisis Marketing Appeal dan Source of Message Terhadap Public Acceptance pada Iklan Pembatasan Transaksi Tunai", Journal of Management and Business Review.

. (2010). "Pembatasan Transaksi Tunai Solusi Pemberantasan Korupsi dan Pencucian Uang Lainnya", Otonomi Rakyat.

. (2014). "Pemberantasan Mafia Dengan Pembatasan Transaksi Tunai", Hukum Online, 16 September.

Transparency International Indonesia. (2014). “Corruption Perceptions Index 2014”, 6 Desember.

The European Central Bank (ECB). (2010). "Opnion of The European Central Bank of 10 November 2010 on Restrictions on Cash Payments".

World Bank. (2003). Basel Committee on Banking Supervision-Bank For International Settlements.

Yusuf, Muhammad. (2015). "PPATK Yakin RUU Pembatasan Transaksi Tunai Selesai 2016", Liputan6.com, 17 April. 